\title{
Comment on GSA Today article by Pavlis et al., 2019: "Subduction Polarity in Ancient Arcs: A Call to Integrate Geology and Geophysics to Decipher the Mesozoic Tectonic History of the Northern Cordillera of North America"
}

\author{
Karin Sigloch, Earth Sciences Dept., University of Oxford, South Parks Road, Oxford OX1 3AN, UK; Mitchell G. Mihalynuk, British \\ Columbia Geological Survey, P.O. Box 933 Stn Prov Govt, Victoria, British Colunbia, V8W 9N3, Canada
}

Pavlis et al. (2019) (abbreviated "P2019") assert that "geologic and geophysical interpretations lead to fundamentally different conclusions regarding the polarity of subduction along the Cordilleran margin during late Mesozoic time" (p. 1). Their paper is a call to defend a model of uninterrupted eastward subduction beneath continental North America (which we refer to as an "alwaysAndean" style model) from purportedly contradictory geophysical observations. Our own work, critically cited 12 times on five pages, shows that no such contradiction exists. Neither geology nor geophysics supports always-Andean style subduction since $200 \mathrm{Ma}$ (Sigloch and Mihalynuk 2013, 2017 [abbreviated "SM12013" and "SM2017"]). Instead, both record a Jura-Cretaceous period of simultaneous eastward and westward subduction under a vast archipelago in the northeastern proto-Pacific, analogous to today's southwestern Pacific. Welded into westward-subducting lithosphere, North America (NAm) was pulled into the Archipelago and diachronously overrode it from ca. 155-50 Ma, accreting its arcs and microcontinents.

P2019 portray our Archipelago model as featuring only westward subduction, then dismiss it by pointing to the Chugach subduction complex of Alaska, clearly derived from eastward subduction. In reality, our Archipelago model features as much eastward subduction as the Andean-style model, just located further west. Its very essence, missed by P2019, is long-lived subduction of two mature oceans beneath the Archipelago from opposite sides. Our Figure 1A corrects P2019's rendering of our model (in their fig. 1 and discussion). Our Figure 1B develops today's Southwest Pacific archipelago as a close tectonic analogue.
The geologic crux of distinguishing between "always Andean" and "Archipelago" models is the fragmentary record of a suture between NAm and the Insular microcontinent (INS; "Wrangellia Composite Terrane"/ WCT of P2019). Heavy overprinting by the Coast Plutonic Complex results in observational gaps and interpretational ambiguities that are perilously discounted by P2019. Both inboard (continentward) and outboard of this overprinted suture, geologic records support Andean-style subduction over two periodsthe "Native" Jurassic-Triassic arc on the cratonic southwestern United States (Dickinson, 2004; Barth et al., 2011; Riggs et al., 2016), and the Cenozoic Cascadia arc in the Pacific Northwest. The "always Andean" model originated as the simplest interpolation between these Jurassic and Cenozoic arcs, with no hypothesis-driven incentive to question Cretaceous times.

Geophysical slab interpretations, including our own (Sigloch et al., 2008; Sigloch, 2011), followed geology's lead in adopting the "always-Andean margin" interpretation up until SM2013. Geologists' faith in the validity of this model crossed the community divide as a certainty cast in stone. Dissent among geologists in favor of Archipelago-like models (Moores, 1970, 1998; Schweickert and Cowan, 1975; Ingersoll and Schweickert, 1986; Cowan, 1994; Ingersoll, 2008) did not rise to audible levels for geophysicists. Also, as long as only the supermassive slab walls under NAm's eastern seaboard were clearly visible to seismic tomography, they had to be interpreted as Farallon lithosphere in order to match the surviving seafloor isochron record (Atwater, 1989; Engebretson et al., 1985). Even a mantle reference frame was constructed to fix the locus of slab deposition to the continental margin (van der Meer et al., 2010; used by P2019 in circular reasoning to support their call). An easterly "Farallon slab" was only seriously questioned once a second set of lower-mantle slabs, more westerly and this time truly Farallon, came into focus under western NAm, thanks to USArray (Sigloch et al., 2008).

P2019 exaggerate the geophysical uncertainties. Two decades after the iconic Farallon slab images of Grand et al. (1997) on the GSA Today cover, not many geophysicists will respond to P2019's call to challenge "the hypothesis that the deep anomalies are indeed subduction zone remnants" (p. 5). P2019 claim serious problems with slab interpretation because, "These slabs are now in the mantle more than $3000 \mathrm{~km}$ from their presumed paleotrench. To restore the pathway over this distance requires multiple assumptions, including the nature of the mantle anomaly, uncertainties in slab sinking rates, and models of absolute plate motion" (p. 2). Confusingly they fail to mention that all these problems (serious indeed) arise only in the "always-Andean" slab interpretation.

Our "tomotectonic" working hypothesis is that a slab indicates the former existence of a trench overhead, because accumulations of lithosphere sink essentially vertically at roughly the same rate everywhereas expected intuitively and supported by simulations (e.g., Steinberger et al., 2012). Massive slab "walls" observed in the lower mantle under NAm must track paleo-trench lines of long-lived, stationary subduction zones (Fig. 1A). Mantle convection under North America, implied to be highly variable over time and space by the "alwaysAndean" model, becomes simple in the Archipelago framework. Quantitative plate 


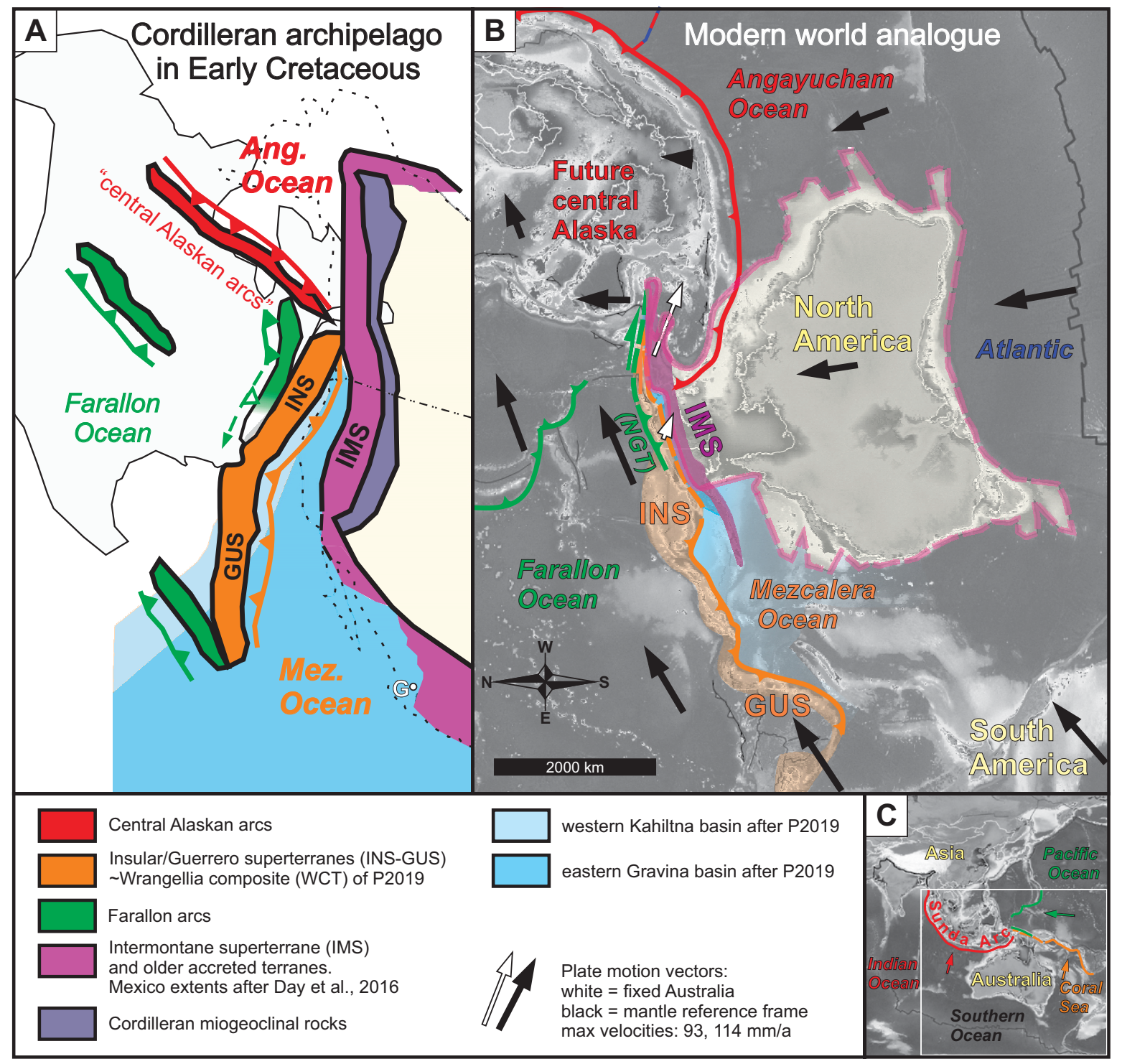

Figure 1. Cordilleran Archipelago in Early Cretaceous times, and its modern-day analogue. (A) Reconstruction of the intra-oceanic Archipelago that was overridden and accreted by North America (NAm) between ca. $150 \mathrm{Ma}$ to ca. $50 \mathrm{Ma}$. Figure is corrected from Figure 1C in Pavlis et al. (2019), who attempted to render the model of Sigloch and Mihalynuk (2017) but omitted all eastward (Farallon) subduction. Present-day location of North America (NAm) is shaded gray; location in early Cretaceous times (ca. 140 Ma) is shaded yellow. Barbed lines are paleo-trench lines inferred from the presence of massive slab walls in the lower mantle; colored patches are associated arc terranes. Green-Farallon trenches and arcs; orange-Mezcalera trenches and arcs, including Insular Superterrane (INS) and Guerrero Superterrane (GUS); red-Angayucham (Ang) trenches and arcs (future Central Alaska). The Mezcalera (Mez.) [Angayucham] Ocean occupies the space between NAm and the Mezcalera [Angayucham] trench. NAm has started to override the archipelago, flipping orange, intra-oceanic, westward subduction to green, "Andean-style," eastward subduction. Intermontane Superterrane (IMS) is a pre-accreted part of the NAm margin. (B) The modern-day southwest Pacific represents a closely analogous archipelago (after Sigloch and Mihalynuk, 2017). Base map was obtained by rotating and mirroring the present-day geography; see compass rose and compare to panel (C). Tectonic elements are colored and labeled to match their Cordilleran counterparts in (A). Dashed purple line, filled pale yellow, delineates Australian continental lithosphere. Its position relative to the archipelago is most analogous to NAm's position ca. $120 \mathrm{Ma}$, shortly after starting to override the archipelago. Subduction polarity has started to flip from orange to green along Australia's New Guinea trench segment (NGT). (C) Present-day southwest Pacific. Modern oceans and trenches are colored analogous to panels (A) and (B).

reconstructions permit positioning of NAm relative to these paleo-trenches, and result in a Jura-Cretaceous NAm position well east of the easternmost trenches (Fig. 1A).

NAm in Figure 1A (or Australia in Fig. 1B) first gets pulled by archipelago-ward subduction, but the polarity must flip to continent-ward after arc override. We agree with P2019 that discriminating geologically from always-continent-ward subduction hinges on establishing the lifetime of the paleoocean basin between INS and NAm, and the timing and polarity of its closure. Slab wall locations and distances to Pangean NAm indicate that the basin was much broader than envisaged by P2019 (blue in Fig. 1A); we name it "Mezcalera Ocean," following Dickinson and Lawton (2001). Slab locations combined with plate tectonic rules indicate that this Mezcalera Ocean closed by westward subduction under the Archipelago's eastern border, with absolute trench locations delineated by the eastern-seaboard slab wall now holding this Mezcalera lithosphere. The associated arc must have been built on the older INS micro-continent (Fig. 1A), hence equated with Talkeetna arc-in 
contention with P2019, who attribute Talkeetna arc to eastward subduction.

P2019 falsely claim that SM2017 "ignored or dismissed a fundamental observation; namely, that there is compelling geologic evidence that subduction along the northern Cordilleran margin has been east-dipping for at least the last $\sim 125$ m.y., and likely can be traced $\sim 75$ m.y. further back into the Late Triassic (p. 1)." Our model admits as much eastward subduction as theirs, and we agree that eastward subduction beneath the continental margin built the "Native arc" from Late Triassic (even Permian in southern NAm) through Early Jurassic times. A corresponding "Native Arc slab" is imaged in the lowermost mantle of today's central Atlantic (Hosseini et al., 2019; SM2017; termed "Atlantis slab" by van der Meer et al., 2010), vertically beneath the reconstructed Triassic margin of NAm (SM2017). This slab is disconnected from the more westerly, shallower Mezcalera slab wall (rather than sloping up toward it - the prediction of "always-Andean" subduction), supporting our hypothesis that INS remained well offshore Pangean NAm.

Our accounting for Chugach complex formation since ca. 145 Ma by Farallon subduction does not differ substantially from P2019. Neither does the genesis of the accretionary Franciscan complex ( $<123 \mathrm{Ma}$; Dumitru et al., 2010), its pairing with the Sierra Nevada arc, and relation to the Mezcalera suture, which are discussed by SM2017. Accretionary phases of both subduction complexes started in the eastern green patches of Figure 1A, where NAm first overrode the northern Mezcalera trench and its INS arc (orange), forcing a subduction direction flip and nucleating a new, "Andean-style" arc in early Cretaceous times. (Analogous trench flip is ongoing north of New Guinea; Fig. 1B.) Additionally, the Chugach complex probably formed offshore above the Cascadia Root (CR) slab, a deep and voluminous slab under the northwest U.S. that is linked (via the Pacific isochron record; Atwater, 1989; Engebretson et al., 1985) with eastward subduction of the northernmost Farallon plate, from $180+$ Ma to today (Sigloch and Mihalynuk, 2013). Any "CR-Chugach" would have accreted to "INS-Chugach" between ca. $90 \mathrm{Ma}$ and the Eocene, the period over which NAm overrode the CR arc (Pacific Rim arc terrane). Thus at least the Chugach's younger history is related to CR slab deposition. Its fragmentary pre-145 Ma record may also be paired with Pacific Rim arc terrane-countering P2019's perceived need to pair Chugach complex with the Talkeetna arc on INS, which our model attributes to Mezcalera westward subduction.

P2019 claim that "there is virtually no evidence for west-dipping subduction anywhere along the inboard margin of the WCT" (p. 2). This representation relies on magmatic overprinting of the suture by the Coast Belt and acceptance of a hypothetical sinistral fault with $\sim 800 \mathrm{~km}$ of offset that was invoked to rationalize Jura-Cretaceous subduction zone relicts inboard of INS (Monger et al., 1994). Relicts may extend to NW Washington where they record 35 m.y. of blueschist metamorphism that ceased between 140 and 136 Ma (Cordova et al., 2019). In fact, SM2017 reviewed observations pertaining to arc polarity along the entire Mezcalera Ocean suture (Figs. 1A, 1B). From Alaska to Mexico, this suture is manifested in a dozen collapsed Jura-Cretaceous basins between INS and previously accreted Intermontane Superterrane (IMS). About half of these basins contain ultramafic rocks that may be mantle relicts. Unravelling the story of these relict basins is hampered by the huge volumes of sediment that normally clog them, the intense folding and thrusting that accompanied final collapse, and their thorough overprinting by the thermal-metamorphic welt of the Coast Plutonic Complex, which extends the length of British Columbia (BC).

None of these suture relicts are currently interpreted as formed by westward subduction, but a simple, first-order observation shows that they should be: a 35-70-m.y.-long hiatus of volcanic arc strata east of the suture, with simultaneous arc construction west of the suture, on INS. The clearest evidence of this arc hiatus exists across the expanse of Bowser Basin in northwest BC (detailed in SM2017). In southern BC, it has long been recognized that strata on the NAm margin (IMS) lack any record of subduction-related volcanism between ca. 175 and $105 \mathrm{Ma}$ (Thorkelson and Smith, 1989; sparse intrusions within this age bracket have since been dated, but are of uncertain petrogenesis, mostly related to metamorphic terranes, and/ or are dated by homogenized, multigrain fractions; e.g., Erdmer et al., 2002). Discovery of rare 163 Ma tuffs on IMS (Mihalynuk et al., 2016) may reduce this volcanic gap, but the petrogenesis of these tuffs is unknown. Regardless, the fundamental observation of an extended arc hiatus east of the suture holds. In mid-coastal BC, Gehrels et al. (2009) note that plutons younger than $160 \mathrm{Ma}$ apparently do not extend eastward from the Coast Belt into IMS (Stikine terrane). In southern Alaska, too, scant evidence for arc-type magmatism exists north and east of the sutured basins (Kahiltna-Nutzotin) during the hiatus period (e.g., Wilson et al., 2015); whereas INS, south of the suture basins includes magmatic belts (Hart et al., 2004) of Early Cretaceous age: 145-135 Ma, followed by a major flareup 118-110 Ma, coeval with suturing of the Nutzotin basin (117-114 Ma; Trop et al., 2019). Hence, the subduction of ocean lithosphere that created accretionary complexes and collapsed basins between INS and IMS was likely beneath INS, a conclusion also reached by Dickinson (2004, p. 28).

We stand by our statement that the Chugach subduction complex should not be paired with the Talkeetna arc because their ages do not match (SM2017; Talkeetna arc formed 207-167 Ma) (Amato et al., 2007) or to $153 \mathrm{Ma}$ (Rioux et al., 2007). This basic requirement is not countered by any of P2019's secondary reasoning. Remarkably, Day, Pavlis, and Amato (2016) themselves advocated a model that allows for pairing of their Chugach complex with an entirely different arc, one that was part of an island archipelago located $\sim 3000 \mathrm{~km}$ to the southeast, with multiple subduction zones having both east and west polarities (cf. their fig. 6 vs. our Fig. 1A).

P2019 express "virtually no doubt" (p. 3) about (north)east-dipping subduction beneath Talkeetna arc because of its northward younging and increasingly silicic plutons. In reality, such observations cannot constrain subduction polarity without a priori knowledge of the slab's position relative to the trench. In southwest BC, Canil et al. (2013) show analogous eastward younging of arc magmatism, and shallowing of exhumation levels, for the Talkeetna-correlative, 202-167 Ma Bonanza arc, and they acknowledge the possibility of trench retreat above a westward-subducting slab.

Our analogue identifies Talkeetna arc with the Coral Sea intra-oceanic trench (Fig. 1B). Chugach's modern analogue is placed continent-ward of the green incipient New Guinea trench. Coupling with the Pacific plate shears these structures westward, analogous to "BajaBC" northward translations of both Chugach complex and Talkeetna arc, through coupling to the Farallon plate (e.g., Day et al., 2016).

NAm paleogeographies need to be consistent with slab geometries, seafloor isochrons, and geologic observations, formulated in a hypothesis-driven work mode that unlocks the full potential of the geological record. 
Now that absolute paleo-positioning is available for Cordilleran subduction zones, it is time to give the place a fresh look.

\section{ACKNOWLEDGMENTS}

Our work is funded by the European Research Council (ERC) under the European Union's Horizon 2020 research and innovation program (grant agreement 639003 "DEEP TIME") and by a Philip Leverhulme Prize awarded by The Leverhulme Trust.

\section{REFERENCES CITED}

Amato, J.M., Rioux, M.E., Kelemen, P.B., Gehrels, G.E., Clift, P.D., Pavlis, T.L., and Draut, A.E., 2007, $\mathrm{U}-\mathrm{Pb}$ geochronology of volcanic rocks from the Jurassic Talkeetna Formation and detrital zircons from prearc and postarc sequences: Implications for the age of magmatism and inheritance in the Talkeetna arc, in Ridgway, K.D., Trop, J.M., Glen, J.M.G., and O'Neill, J.M., eds., Tectonic Growth of a Collisional Continental Margin: Crustal Evolution of Southern Alaska: Geological Society of America Special Paper 431, p. 253-271, https://doi .org/10.1130/2007.2431(11).

Atwater, T., 1989, Plate tectonic history of the northeast Pacific and western North America, in Winterer, E.L., et al., eds., The Eastern Pacific Ocean and Hawaii: Boulder, Colorado, Geological Society of America, Geology of North America, v. N, p. 21-72.

Barth, A.P., Walker, J.D., Wooden, J.L., Riggs, N.R., and Schweickert, R.A., 2011, Birth of the Sierra Nevada magmatic arc: Early Mesozoic plutonism and volcanism in the east-central Sierra Nevada of California: Geosphere, v. 7, p. 877-897, https://doi .org/10.1130/GES00661.1.

Canil, D., Johnston, S.T., Larocque, J., Friedman, R., and Heaman, L.M., 2013, Age, construction, and exhumation of the midcrust of the Jurassic Bonanza arc, Vancouver Island, Canada: Lithosphere, v. 5, p. 82-91, https://doi.org/10.1130/L225.1.

Cordova, J.L., Mulcahy, S.R., Schermer, E.R., and Webb, L.E., 2019, Subduction initiation and early evolution of the Easton metamorphic suite, northwest Cascades, Washington: Lithosphere, v. 11, p. 44-58, https://doi.org/10.1130/L1009.1.

Cowan, D.S., 1994, Alternative hypotheses for the Mid-Cretaceous paleogeography of the Western Cordillera: GSA Today, v. 4, p. 181, 184-186.

Day, E.M., Pavlis, T.L., and Amato, J.M., 2016, Detrital zircon ages indicate an Early Cretaceous episode of blueschist-facies metamorphism in southern Alaska: Implications for the Mesozoic paleogeography of the northern Cordillera: Lithosphere, v. 8, p. 451-462, https://doi.org/10.1130/ L525.1.

Dickinson, W.R., 2004, Evolution of the North American Cordillera: Annual Review of Earth and Planetary Sciences, v. 32, p. 13-45, https://doi.org/ 10.1146/annurev.earth.32.101802.120257.

Dickinson, W.R., and Lawton, T.F., 2001, Carboniferous to Cretaceous assembly and fragmentation of Mexico: Geological Society of America Bulletin, v. 113, p. 1142-1160, https://doi.org/10.1130/0016 -7606(2001)113<1142:CTCAAF $>2.0 . \mathrm{CO} ; 2$.

Dumitru, T.A., Wakabayashi, J., Wright, J.E., and Wooden, J.L., 2010, Early Cretaceous transition from nonaccretionary behavior to strongly accretionary behavior within the Franciscan subduction complex: Tectonics, v. 29, no. 5, https://doi.org/ 10.1029/2009TC002542.
Engebretson, D.C., Cox, A., and Gordon, R.G., 1985, Relative motions between oceanic and continental plates in the Pacific basin: Geological Society of America Special Paper 206, 60 p., https://doi.org/ 10.1130/SPE206-p1.

Erdmer, P., Moore, J.M., Heaman, L., Thompson, R.I., Daughtry, K.L., and Creaser, R.A., 2002, Nicola horst, southern British Columbia: Canadian Journal of Earth Sciences, v. 39, no. 11, p. 1605, https:// doi.org/10.1139/e02-072.

Gehrels, G., Rusmore, M., Woodsworth, G., Crawford, M., Andronicos, C., Hollister, L., Patchett, J., Ducea, M., Butler, R., Klepeis, K., and Davidson, C., 2009, U-Th-Pb geochronology of the Coast Mountains batholith in north-coastal British Columbia: Constraints on age and tectonic evolution: Geological Society of America Bulletin, v. 121, no. 9-10, p. 1341-1361, https://doi.org/10.1130/ B26404.1.

Grand, S.P., van der Hilst, R.D., and Widiyantoro, S., 1997, Global seismic tomography: A snapshot of convection in the Earth: GSA Today, v. 7, no. 4, p. 1-7.

Hart, C.J., Goldfarb, R.J., Lewis, L.L., and Mair, J.L., 2004, The Northern Cordilleran Mid-Cretaceous Plutonic Province: Ilmenite/magnetite-series granitoids and intrusion-related mineralisation: Resource Geology, v. 54, p. 253-280, https://doi.org /10.1111/j.1751-3928.2004.tb00206.x.

Hosseini, K., Sigloch, K., Tsekhmistrenko, M., Zaheri, A., Nissen-Meyer, T., and Igel, H., 2020, Global mantle structure from multifrequency tomography using P, PP and P-diffracted waves: Geophysical Journal International, v. 220, no. 1, p. 96-141, https://doi.org/10.1093/gji/ggz394.

Ingersoll, R.V., 2008, Subduction-related sedimentary basins of the USA Cordillera: Sedimentary Basins of the World, v. 5, p. 395-428, https://doi.org/ 10.1016/S1874-5997(08)00011-7.

Ingersoll, R.V., and Schweickert, R.A., 1986, A platetectonic model for Late Jurassic Ophiolite Genesis, Nevadan orogeny and forearc initiation, northern California: Tectonics, v. 5, p. 901-912, https://doi .org/10.1029/TC005i006p00901.

van der Meer, D.G., Spakman, W., van Hinsbergen, D.J.J., Amaru, M.L., and Torsvik, T.H., 2010, Towards absolute plate motions constrained by lower-mantle slab remnants: Nature Geoscience, v. 3, p. 36-40, https://doi.org/10.1038/ngeo708.

Mihalynuk, M.G., Diakow, L.J., Friedman, R.M., and Logan, J.M., 2016, Chronology of southern Nicola arc stratigraphy and deformation, in Geological Fieldwork 2015, British Columbia Ministry of Energy and Mines: British Columbia Geological Survey Paper 2016-1, p. 31-63.

Monger, J.W.H., Van der Heyden, P., Journeay, J.M., Evenchick, C.A., and Mahoney, J.B., 1994, Jurassic-Cretaceous basins along the Canadian Coast Belt: Their bearing on pre-mid-Cretaceous sinistral displacements: Geology, v. 22, p. 175-178, https://doi.org/10.1130/0091-7613(1994) 022 $<0175$ :JCBATC $>2.3$.CO; 2 .

Moores, E., 1970, Ultramafics and orogeny, with models of the US Cordillera and the Tethys: Nature, v. 228, p. 837-842, https://doi.org/10.1038/ $228837 \mathrm{a} 0$.

Moores, E.M., 1998, Ophiolites, the Sierra Nevada, "Cordilleria," and orogeny along the Pacific and Caribbean margins of North and South America: International Geology Review, v. 40, p. 40-54, https://doi.org/10.1080/00206819809465197.
Pavlis, T.L., Amato, J.M., Trop, J.M., Ridgway, K.D., Roeske, S.M., and Gehrels, G.E., 2019, Subduction polarity in ancient arcs: A call to integrate geology and geophysics to decipher the Mesozoic tectonic history of the northern Cordillera of North America: GSA Today, v. 29 , no. 11 , p. $4-10$, https://doi .org/10.1130/GSATG402A.1.

Riggs, N.R., Oberling, Z.A., Howell, E.R., Parker, W.G., Barth, A.P., Cecil, M.R., and Martz, J.W., 2016, Sources of volcanic detritus in the basal Chinle Formation, southwestern Laurentia, and implications for the Early Mesozoic magmatic arc: Geosphere, v. 12, p. 439-463, https://doi.org/ 10.1130/GES01238.1.

Rioux, M., Hacker, B., Mattinson, J., Kelemen, P., Blusztajn, J., and Gehrels, G., 2007, Magmatic development of an intra-oceanic arc: High-precision $\mathrm{U}-\mathrm{Pb}$ zircon and whole-rock isotopic analyses from the accreted Talkeetna arc, south-central Alaska: Geological Society of America Bulletin, v. 119, p. 1168-1184, https://doi.org/10.1130/B25964.1.

Schweickert, R.A., and Cowan, D.S., 1975, Early Mesozoic tectonic evolution of the western Sierra Nevada, California: Geological Society of America Bulletin, v. 86, no. 10, p. 1329-1336.

Sigloch, K., 2011, Mantle provinces under North America from multifrequency P-wave tomography: Geochemistry, Geophysics, Geosystems, v. 12, https://doi.org/10.1029/2010gc003421.

Sigloch, K., and Mihalynuk, M.G., 2013, Intra-oceanic subduction shaped the assembly of Cordilleran North America: Nature, v. 496, p. 50-56, https:// doi.org/10.1038/nature12019.

Sigloch, K., and Mihalynuk, M.G., 2017, Mantle and geological evidence for a Late Jurassic-Cretaceous suture spanning North America: Geological Society of America Bulletin, v. 129, p. 1489-1520, https://doi.org/10.1130/B31529.1.

Sigloch, K., McQuarrie, N., and Nolet, G., 2008, Twostage subduction history under North America inferred from multiple-frequency tomography: Nature Geoscience, v. 1, p. 458-462, https://doi.org/ 10.1038/ngeo231.

Steinberger, B., Torsvik, T.H., and Becker, T.W., 2012, Subduction to the lower mantle-A comparison between geodynamic and tomographic models: Solid Earth, v. 3, p. 415-432, https://doi .org/10.5194/se-3-415-2012.

Thorkelson, D.J., and Smith, A.D., 1989, Arc and intraplate volcanism in the Spences Bridge Group: Implications for Cretaceous tectonics in the Canadian Cordillera: Geology, v. 17, p. 1093-1096, https://doi .org/10.1130/0091-7613(1989)017<1093:AAIVIT> 2.3.CO;2.

Trop, J.M., Benowitz, J.A., Koepp, D.Q., Sunderlin, D., Brueseke, M.E., Layer, P.W., and Fitzgerald, P.G., 2019, Stitch in the ditch: Nutzotin Mountains (Alaska) fluvial strata and a dike record ca. 117-114 Ma accretion of Wrangellia with western North America and initiation of the Totschunda fault: Geosphere, v. 16, no. 1, p. 82-110, https://doi.org/ 10.1130/GES02127.1.

Wilson, F.H., Hults, C.P., Mull, C.G., and Karl, S.M., 2015, Geologic map of Alaska: U.S. Department of the Interior, U.S. Geological Survey Scientific Investigations Map 3340, pamphlet 196 p., 2 sheets, scale 1: $1,584,000$

MANuSCRIPT ReCEIVEd 4 JAN. 2020

REVISED MANUSCRIPT RECEIVED 26 Apr. 2020

MANUSCRIPT ACCEPTED 28 ApR. 2020 